\title{
Biological Grandchild
}

National Cancer Institute

\section{Source}

National Cancer Institute. Biological Grandchild. NCI Thesaurus. Code C100805.

A biological child of an individual's biological child. 